\title{
Keberhasilan Kebijakan Pengampunan Pajak (Tax Amnesty) di Indonesia
}

\author{
Budi Ispriyarso \\ Fakultas Hukum Universitas Diponegoro \\ budiispriyarso@ymail.com
}

\begin{abstract}
The Indonesian government has carried out a tax amnesty policy in 2016. The background for the tax amnesty policy is, among other things, the wealth of Indonesian citizens who have not or have not all been reported in the Annual Notice. Some of the objectives of the tax amnesty, among others, are in the short term to increase tax revenues, the long-term goals include strengthening domestic liquidity, increasing investment, accelerating tax reforms and increasing tax revenues. The problem is whether the tax amnesty carried out by the Indonesian government succeeded, what was the negative side of the implementation of the tax amnesty. Tax amnesty in Indonesia from ransom receipts specifically from the declaration can be said to be successful, but the repatriation failed and the number of participants participating in the tax amnesty program was not as expected. The negative side of the tax amnesty is the tax amnesty, giving rise to a sense of injustice especially for obedient taxpayers, the tax amnesty can lead to non-compliance of taxpayers because they hope that a future tax amnesty and tax amnesty are not in accordance with the principles of law enforcement.
\end{abstract}

Keywords: Tax Amnesty, success and ransom

\begin{abstract}
Abstrak
Pemerintah Indonesia telah melakukan kebijakan pengampunan pajak (Tax Amnesty ) pada tahun 2016. Latar belakang dilakukannya kebijakan tax amnesty tersebut, antara lain adalah karena banyaknya harta warga negara Indonesia yang belum atau belum semuanya dilaporkan dalam Surat Pemeritahuan Tahunan. Beberapa tujuan tax amnesty, antara lain adalah dalam jangka pendeknya meningkatkan penerimaan perpajakan, tujuan jangka panjangnya antara lain adalah memperkuat likuiditas domestik, peningkatan investasi, mempercepat reformasi perpajakan dan meningkatkan penerimaan pajak. Permasalahannya adalah apakah tax amnesty yang dilakukan pemerintah Indonesia berhasil, apa saja yang menjadi sisi negatif dari pelaksanaan tax amnesty tersebut. Tax amnesty di Indonesia dari penerimaan tebusan khususnya dari deklarasi dapat dikatakan berhasil, namun dari repatriasinya gagal dan dari jumlah peserta yang mengikuti program tax amnesty tidak seperti yang diharapkan. Sisi negatif dari tax amnesty adalah tax amnesty, menimbulkan rasa ketidak adilan khususnya bagi wajib pajak yang patuh, tax amnesty dapat menimbulkan ketidakpatuhan wajib pajak karena berharap ada tax amnesty di masa yang akan datang dan tax amnesty tidak sesuai dengan prinsip penegakan hukum.
\end{abstract}

Kata kunci : Tax Amnesty, keberhasilan dan uang tebusan 


\section{A. Pendahuluan}

Beberapa tahun yang lalu tepatnya tahun 2016, pemerintah Indonesia telah melakukan suatu kebijakan di bidang perpajakan yang merupakan upaya "terobosan" pemerintah dalam memperoleh dana dalam jangka waktu yang lebih cepat. Kebijakan tersebut adalah kebijakan Pengampunan Pajak atau yang dikenal dengan Tax Amnesty. Tujuan jangka pendeknya adalah meningkatkan penerimaan negara dari sektor perpajakan. Tax amnesty diberlakukan di Indonesia, didasarkan pada Undang-undang Nomor 11 Tahun 2016 tentang Pengampunan Pajak.

Berbeda dengan prinsip penegakan hukum (Law enforcement) di bidang perpajakan, yang pada prinsipnya pelaksanaan ketentuan perpajakan harus dilakukan secara konsekuen, ${ }^{1}$ bagi wajib pajak yang kurang/tidak patuh harus dikenakan sanksi yang berlaku, program tax amnesty sebaliknya justru memberikan pengampunan kepada wajib pajak dengan membayar sejumlah uang tebusan.

Tax amnesty dilakukan pemerintah Indonesia dilakukan di tengah-tengah ekonomi yang lesu sebagai "senjata" yang ampuh untuk mendapatkan penerimaan negara yang diinginkan demi keberlanjutan program-program pemerintah. Tax amnesty dilakukan untuk menarik "uang"dari warga negara Indonesia yang disinyalir menyimpan uangnya secara rahasia di negara negara bebas pajak seperti di Panama atau di negara-negara lain.Harapan pemerintah dengan adanya program tax amnesty ini dengan uang tebusan yang sangat murah, dapat menarik minat warga negara Indonesia untuk mengalihkan simpanannya atau berinvestasi ke dalam negeri.

Pemerintah Indonesia tidak sendirian dalam program tax amnesty ini. Di tengah perlambatan ekonomi dunia puluhan negara juga saat ini tengah menjalankan program tax amnesty untuk memperebutkan dana global. Situasi ini sangat didukung oleh makin gencarnya negara-negara besar yang tergabung dalam G-20, yang dimotori oleh Amerika Serikat dan negara-negara maju lain, untuk melacak harta warga negaranya yang disimpan di negara-negara tax haven. Sebagai realisasi dibentuklah suatu sistem pertukaran data keuangan antarnegara partisipan yang disebut Automatic Exchange of Information (AEoI ). ${ }^{2}$ Indonesia juga sudah menandatangani Multilateral Competent Authority Agreement (MCAA) yang di dalam Annex F-nya mencantumkan komitmennya untuk memulai AeoI pada tahun

\footnotetext{
1 Panca Kurniawan, Bagus Pamungkas, Penagihan Hukum Pajak Di Indonesia, Malang:Bayumedia Publishing,2016 halaman viii.

2 https://www.kompasiana.com/ojidnatus/577a2c5eaf7e613d4a8cdf18/dampak-program-pengampunan-pajaktax-amnesty, diakses tangal 19 April 2019.
} 
2018. ${ }^{3}$ Melalui perjanjian antar negara tersebut,seluruh data terkait perbankan seperti deposito, investasi dan instrumen keuangan lainnya akan dapat diketahui oleh otoritas pajak di dunia. ${ }^{4}$

Menurut "UU No 11 Tahun 2016 Tentang Pengampunan Pajak" Tax Amnesty adalah sebuah penghapusan pajak yang seharusnya terutang, tidak dikenai sanksi administrasi perpajakan dan sanksi pidana di bidang perpajakan, dengan cara mengungkap Harta dan membayar Uang Tebusan.(Pasal 1 angka 1 ). Kebijakan tax amnesty ini yang telah dilaksanakan pemerintah pada tahun 2016 dan berakhir pada tahun 2017. Permasalahannya adalah apakah kebijakan tax amnesty yang dilakukan pemerintah Indonesia ini dapat dikatakan berhasil ataukah sebaliknya.Apa saja yang menjadi sisi negatif dari kebijakan tax amnesty tersebut.

\section{B. Pembahasan}

\section{Tinjauan Umum tentang Tax Amnesty di Indonesia}

Tax amnesty tidak hanya dilakukan oleh pemerintah Indonesia, negara-negara lain juga telah melakukan tax amnesty, antara lain adalah Australia, Belgia, Kanada, Portugal, Rusia, Afrika Selatan, Jerman, Yunani, Amerika Serikat. Kebijakan tax amnesty yang dilakukan oleh beberapa negara di dunia ini, tujuan utamanya antara lain adalah untuk menarik dana para wajib pajak yang tersimpan secara rahasia di negara negara "bebas pajak", sehingga diharapkan dengan pemasukan dana ini dapat dipergunakan untuk menunjang pelaksanaan program-program pemerintah.

Pemerintah Indonesia, melakukan tax amnesty pada tahun 2016 dengan berdasarkan Undang-undang Nomor 11 tahun 2016 tentang Pengampunan Pajak. Program pemerintah tentang Pengampunan Pajak (Tax Amnesty) berlaku dalam waktu yang sangat singkat yaitu selama 9 bulan (1 Juli 2016 s.d. 31 Maret 2017) dan Presiden Jokowi menyampaikan bahwa program Amnesti Pajak ini merupakan yang terakhir kali dan tidak akan ada lagi dikemudian hari, karena kedepan dengan adanya keterbukaan informasi maka Direktorat Jenderal Pajak akan mendapat akses ke semua data Wajib Pajak termasuk data perbankan baik di dalam maupun di luar negeri. ${ }^{5}$

Pengertian tax amnesty adalah program pengampunan yang diberikan oleh Pemerintah kepada Wajib Pajak meliputi penghapusan pajak terutang, penghapusan sanksi

\footnotetext{
${ }^{3}$ Djangkung Sudjarwadi, "Sosialisasi Akses Informasi Keuangan Bagi Perpajakan", Round Table Discussion, Fakultas Hukum Universitas Diponegoro, Semarang, 14 Juni 2017, halaman 6

${ }^{4}$ Nufransa Wira Sakti, Asrul Hidayat, Tax Amnesty itu Mudah, Jakarta : Visimedia,2016, halaman 5.

${ }^{5}$ http://www.infopajak.id/aplikasi-tax-amnesty, diakses 19 april 2019
} 
administrasi perpajakan, serta penghapusan sanksi pidana di bidang perpajakan atas harta yang diperoleh pada tahun 2015 dan sebelumnya yang belum dilaporkan dalam SPT, dengan cara melunasi seluruh tunggakan pajak yang dimiliki dan membayar uang tebusan.

Pasal 1 angka 1 UU Pengampunan Pajak menyebutkan bahwa Pengampunan Pajak adalah penghapusan pajak yang seharusnya terutang, tidak dikenai sanksi administrasi perpajakan dan sanksi pidana di bidang perpajakan, dengan cara mengungkap Harta dan membayar Uang Tebusan sebagaimana diatur dalam Undang-Undang ini.

Dasar Hukum Pengampunan pajak adalah :

- $\quad$ UU Nomor 11 Tahun 2016 tentang Pengampunan Pajak

- Peraturan Menkeu Nomor 118/PMK 03/2016 tentang Pelaksanaan UU Nomor 11 tahun 2016 tentang Pengampunan Pajak.

- Peraturan Menkeu Nomor 119/PMK.03/2016 tentang Penetapan Bank persepsi yang bertindak sebagai penerima uang tebusan dalam rangka pelaksanaan Pengampunan Pajak

- Peraturan Dirjen Pajak PER 07/PJ/2016

- $\quad$ SE dirjen Pajak No. SE -30/PJ/2016

Tujuan Pengampunan Pajak sebagaimana disebutkan dalam Pasal 2 ayat (2) UU Pengampunan pajak adalah sebagai berikut :

a. mempercepat pertumbuhan dan restrukturisasi ekonomi melalui pengalihan Harta, yang antara lain akan berdampak terhadap peningkatan likuiditas domestik, perbaikan nilai tukar Rupiah, penurunan suku bunga, dan peningkatan investasi;

b. mendorong reformasi perpajakan menuju sistem perpajakan yang lebih berkeadilan serta perluasan basis data perpajakan yang lebih valid, komprehensif, dan terintegrasi; dan

c. meningkatkan penerimaan pajak, yang antara lain akan digunakan untuk pembiayaan pembangunan.

Berdasarkan uraian di atas, secara singkat dapat dikatakan bahwa tujuan tax amnesty Ada tiga tujuan yang menjadi target pelaksanaan tax amnesty di Indonesia. Pertama, meningkatkan likuiditas domestic, penurunan suku bunga dan investasi dan perbaikan nilai tukar rupiah melalui pengalihan harta.Kedua, mempercepat reformasi perpajakan dan ketiga, meningkatkan penerimaan negara dari pajak.

Adapun yang menjadi latar belakang Tax Amnesty di Indonesia adalah sebagai berikut : 
a. Tax Amnesty diberlakukan di Indonesia karena banyaknya harta milik warna negara Indonesia baik yang di dalam atau diluar negeri yang belum atau belum semuanya dilaporkan dalam Surat Pemberitahuan Tahunan Pajak Penghasilan.

b. Tax Amnesty bertujuan untuk meningkatkan penerimaan negara dan pertumbuhan perekonomian serta untuk kesadaran dan kepatuhan masyarakat dalam melaksanakan kewajiban membayar pajak, maka dari itu menerbitkan kebijakan Pengampunan Pajak.

c. Kasus Panama Pappers, yaitu sebuah dokumen yang mencantumkan banyaknya pengusaha yang memiliki harta diluar negeri, terutama di negara-negara yang bebas pajak seperti negara Panama.

Tax amnesty (pengampunan pajak) di Indonesia dilakukan melalui tiga periode. Periode pertama berlangsung dari 28 Juni 2016-30 September 2016, dilanjutkan periode kedua yang mulai dari 1 Oktober 2016-31 Desember 2016, periode ketiga berlangsung pada 1 Januari 2017-31 Maret 2017. Wajib pajak yang ingin mengikuti program pengampunan pajak sebaiknya memperhatikan periodisasi pemberlakuan pengampunan pajak berikut besarnya uang tebusan. Hal ini dikarenakan ada perbedaan mengenai besarnya uang tebusan pada tiap-tiap periode tersebut, yaitu sebagai berikut :

a. Tarip pengampunan pajak untuk pengungkapan harta yang berada dalam negeri :

Periode I : $2 \%$,

Periode II : $3 \%$

Periode III : $5 \%$

b. Tarip pengampunan pajak untuk pengungkapan harta yang di luar negeri (jika hartanya tidak dialihkan ke dalam negeri) :

Periode I : $4 \%$

Periode II : $6 \%$

Periode III : $10 \%$

c. Tarip pengampunan pajak untuk pengungkapan harta di luar negeri yang dialihkan ke dalam negeri (repatriasi) :

Periode I : $2 \%$

Periode II : $3 \%$

Peroiode III : $5 \%$

d. Tarip pengampunan pajak untuk UMKM (Usaha Mikro Kecil dan Menengah) yang peredaran usahanya tidak lebih dari 4,8 Miliar (sejak diundangkan sampai dengan 31 Maret 2017 ) : 
0,5\% jika hartanya yang diungkapkan tidak lebih dari 10 miliar

$2 \%$ jika hartanya yang diungkapkan lebih dari 1 miliar

Disamping adanya tarip uang tebusan yang murah, pemerintah memberikan beberapa kemudahan kepada wajib pajak yang ingin mengikuti program tax amnesty. Kemudahankemudahan tersebut seperti: dihapuskannya sanksi administratif, ditiadakannya pemeriksaan pajak untuk penindakan dengan tujuan pidana,penghapusan segala pajak-pajak yang terutang, Penghentian pemeriksaan pajak bagi yang sedang diperiksa, Tidak dikenakannya PPh Final untuk pengalihan harta berupa saham, bangunan, atau tanah. Khusus bagi wajib pajak yang menyimpan hartanya di negara lain, mereka harus merepatriasi hartanya atau menyalurkan hartanya yang selama ini tersimpan di luar untuk diinvestasikan di Indonesia selama tiga tahun. Investasi tersebut dapat berbentuk obligasi BUMN, investasi keuangan pada bank dalam negeri, obligasi perusahaan-perusahaan dalam negeri, kerjasama dengan pemerintah atau badan usaha sebagai investasi pada pembangunan infrastruktur, obligasi lembaga pembiayaan pemerintah, dan investasi lain yang sesuai dengan ketentuan perundangundangan. ${ }^{6}$

Subyek pengampunan pajak diatur dalam Bab III khususnya Pasal 3 UU Pengampunan Pajak. Subyek pengampunan pajak adalah semua wajib pajak berhak atas pengampunan pajak, dengan cara mengungkapkan harta yang dimilikinya melalui surat pernyataan. Pihak yang dapat memanfaatkan pengampunan pajak adalah :Wajib Pajak Orang Pribadi,Wajib Pajak Badan,Wajib Pajak yang bergerak di bidang Usaha Mikro Kecil dan Menengah(UMKM), Orang Pribadi atau Badan yang belum menjadi Wajib Pajak.Sedangkan yang dikecualikan dari subyek pengampunan pajak adalah wajib pajak yang : dilakukan penyidikan dan berkas penyidikannya telah dinyatakan lengkap oleh Kejaksaan, dalam proses peradilan; atau menjalani hukuman pidana,atas Tindak Pidana di Bidang Perpajakan. Jenis pajak yang menjadi obyek pengampunan pajak adalah ( Pasal 4 UU Pengampunan Pajak) :Pajak Penghasilan (PPh), PPN (Pajak Pertambahan Nilai Barang dan Jasa), Pajak Penjualan atas Barang Mewah (PPn BM).

\section{Keberhasilan Kebijakan Tax Amnesty di Indonesia}

Sebagaimana diuraikan di atas, bahwa tax amnesty telah dilakukan pemerintah Indoonesia kurang lebih 3 (tiga) tahun yang lalu. Apakah tax amnesty yang dilakukan

\footnotetext{
${ }^{6}$ https://www.online-pajak.com/tax-amnesty-dan-tujuannya-di-indonesia, diakses 20 April 2019.
} 
pemerintah telah berhasil. Mengenai berhasil atau tidaknya tax amnesty tentang pelaksanaan tax amnesty ini, dapat dilihat dari hal-hal sebagai berikut :

Pertama, jumlah peserta tax amnesty ,peserta (wp yang ikut tax amnesty) yang paling banyak adalah periode I yaitu sejumlah 393.358, selanjutnya pada periode ke dua mengalami penurunan menjadi 223.000 , namun kemudian di periode ke 3 mengalami kenaikan menjadi 356.172 . Jumlah total yang ikut tax amnesty adalah 972.530 , sebagian dari peserta tax amnesty merupakan wajib pajak baru yaitu 52.757. Peserta tax amnesty tersebut terdiri dari orang pribadi non UMKM (Usaha Mikro Kecil dan Menengah), Orang pribadi UMKM, Badan non UMKM, Badan UMKM.Orang pribadi non UMKM merupakan peserta terbanyak tax amnesty diantara peserta lainnya. Jumlah peserta tax amnesty tersebut masih belum sesuai yang diharapkan. Hal ini seperti yang diungkapkan oleh Sri Mulyani bahwa program pengampunan pajak yang dijalankan pemerintah belum banyak dimanfaatkan oleh para wajib pajak. $^{7}$ Tingkat partisipasi Wajib Pajak (WP) yang memanfaatkan amnesti pajak masih rendah. Total jumlah WP yang ikut mencapai 891.577 WP, di mana jumlah itu jauh lebih sedikit dibandingkan dengan WP wajib lapor Surat Pemberitahuan (SPT) yang mencapai 20,1 juta. Apalagi jumlah WP yang memiliki nomor pokok wajib pajak (NPWP) mencapai 32,7 juta. $^{8}$

kedua, Target tax amnesty yang dicanangkan pemerintah,harta deklarasi Rp.4000 triliun,repatriasi Rp.1000 triliun dan uang tebusan 165 triliun.Dari sisi pencapaian target, maka pemerintah berhasil dalam pencapaian target deklarasi yaitu Rp.4.734 triliun (melebihi target Rp.4000 triliun). Sedangkan dua sisi lainnya, tidak mencapai target yaitu uang tebusan sebesar Rp.135 trilun dari target Rp.165 triliun, dan repatriasi Rp.147 triliun dari target Rp.1000 triliun. Dengan perkataan lain pengampunan pajak dari sisi deklarasi berhasil karena melebihi target Rp 4.000 triliun namun repatriasi dianggap gagal karena hanya mencapai kurang dari 15\% dari target Rp1.000 triliun. Berdasarkan jumlah uang tebusan yang masuk sejumlah 135 triliun, merupakan pemasukan paling besar diantara negara-negara di dunia yang telah mengikuti tax amnesty. Dibandingkan negara-negara lain yang menerapkan kebijakan tax amnesty, Indonesia menempati ranking pertama. Jumlah uang tebusan hasil tax amnesty Indonesia adalah135 triliun. sedangkan negara-negara lain :

1. Chili : 20,7 T

2. Italia : $54,2 \mathrm{~T}$

\footnotetext{
${ }^{7}$ Kompas com.23-2-2017

${ }^{8}$ https://bisnis.tempo.co/read/861850/beberapa-penyebab-target-tax-amnesty-tak-tercapai, diakses tgl 21 April 2019.
} 
3. Spanyol : $15,5 \mathrm{~T}$

4. Belgia $: 5,9 \mathrm{~T}$

5. Afrika Selatan : $2,8 \mathrm{~T}$

6. Jerman : 11,3 T

7. India $: 1,4 \mathrm{~T}$

8. Australia : $7,4 \mathrm{~T}$

9. Indonesia : $135 \mathrm{~T}$

Jumlah penerimaan uang dari tax amnesty Rp. $135 \mathrm{~T}$ berasal dari, uang tebusan sebesar Rp.114,23 T, pembayara uang tunggakan sebesar Rp. 19, 01 T, pembayaran bukti permulaaan Rp.1, $74 \mathrm{~T}$ (sumber DJP). Berdasarkan uraian di atas, maka dapat diketahui bahwa pelaksanaan tax amnesty di Indonesia dari aspek penerimaan /pemasukan tax amnesty cukup berhasil khususnya dari aspek deklarasi namun kurang berhasil dalam repatriasi. Ada beberapa hal yang bisa dipakai sebagai alasan untuk menjelaskan rendahnya realisasi dana repatriasi, misalnya keterkaitan repatriasi dengan tingkat kepercayaan dan kredibilitas daya saing investasi di Indonesia. Mungkin banyak WNI yang memiliki harta di luar negeri cenderung merasa asetnya lebih aman jika tetap berada di luar negeri. ${ }^{9}$ Disamping itu , dari peserta yang ikut tax amnesty belum sesuai yang diharapkan.

Secara umum pemerintah menyatakan dalam pelaksanaan tax amnesty di Indonesia cukup berhasil khususnya dari dana penerimaan tax amnesty. namun disisi lain Direktorat Jenderal Pajak (Ditjen Pajak) mengakui, program pengampunan pajak alias tax amnesty dianggap gagal oleh beberapa kalangan pengamat. Kegagalan tax amnesty itu antara lain disampaikan oleh peneliti indef, Mohammad Reza Hanif yang menyatakan ada 3 kegagalan tax amnesty, yaitu : ${ }^{10}$

1. kegagalan dilihat dari mandat UU Tax Amnesty. Menurutnya, di Pasal 2 ayat 2 itu disebut tujuan tax amnesy ada tiga.,yaitu mempercepat pertumbuhan dan restrukturisasi ekonomi melalui pengalihan harta, antara lain akan berdampak terhadap peningkatan likuiditas domestik, perbaikan nilai tukar rupiah, penurunan suku bunga dan peningkatan investasi. Ketiga tujuan ini, tidak tercapai.

2. Kegagalan kedua adalah uji statistik pengaruh repatriasi terhadap variable tujuan pasal 2 ayat 2 huruf a UU Pengampunan Pajak itu ternyata tak tercapai. Karena secara

\footnotetext{
${ }^{9}$ https://pinterpolitik.com/keberhasilan-kegagalan-tak-terduga-tax-amnesty/, diakses tgl 21 April 2019

10 https://www.wartaekonomi.co.id/read136804/indef-buka-empat-kegagalan-amnesti-pajak.html, diakses 21 april 2019.
} 
statistik repatriasi itu tak berpengaruh secara signifikan. Variabel-variabel seperti likuiditas dan nilai tukar justru lebih terpengaruh oleh kondisi ekonomi global dan daya saing investasi.

3. tujuan menambah database wajib pajak pasca tax amnesty belum optimal. "Total peserta tax amnesty yang minim sebesar $965.983 \mathrm{WP}$ atau hanya 2,95 persen dari WP terdaftar 2016, akan berdampak pada database potensi WP ke depan.

4. tebusan tax amnesty yang tak sesuai target. Mencapai Rp114 triliun dari targetnya Rp165 triliun. Selama ini, tebusan tersebut hanya sebagai legitimasi shortfall dan melebarnya defisit APBN Perubahan 2016 lalu.

Secara singkat dapat dikatakan bahwa tax amnesty di Indonesia telah berhasil dari jumlah penerimaan dananya khususnya yang berasal dari deklarasi, namun kurang berhasil dari aspek repatriasi. Demikian juga tentang peserta yang ikut tax amnesty belum sesuai yang diharapkan. Beberapa catatan yang menjadi sisi negatif dari pelaksanaan tax amnest adalah sebagai berikut :

\section{Menimbulkan rasa ketidak adilan khususnya bagi wajib pajak yang patuh;}

Akibat negatip dari diterapkannya tax amnesty ini antara lain adalah dapat menimbulkan ketidak adilan. Ketidak adilan ini dirasakan oleh masyarakat yang selama ini patuh membayar pajak. Mereka merasa diperlakukan tidak adil karena terhadap wajib pajak yang tidak/ kurang patuh justru mendapat pengampunan pajak yang tarip pajaknya jauh lebih ringan daripada tarip pajak wajib pajak yang patuh.

Sebagaimana tersebut di atas, bahwa dalam tax amnesty ini, wajib pajak yang ikut tax amnety ini mendapatkan beberapa fasilitas sebagai berikut :

- Penghapusan pajak terutang yang belum diterbitkan ketetapan pajak. Tidak dikenai sanksi administrasi perpajakan, dan tidak dikenai sanksi pidana perpajakan, untuk kewajiban perpajakan dalam masa pajak, bagian tahun pajak, dan tahun pajak, sampai dengan akhir tahun pajak terakhir.

- Penghapusan sanksi administrasi perpajakan berupa bunga, atau denda, untuk kewajiban perpajakan dalam masa pajak, bagian tahun pajak, dan tahun pajak, sampai dengan akhir tahun pajak terakhir," Pasal 23 Peraturan Menteri Keuangan (PMK) Nomor 118/PMK.03/2016 tentang Pelaksanaan UU Nomor 11 Tahun 2016 tentang Pengampunan Pajak, seperti dikutip dari situs kemenkeu.go.id, Selasa (19/7/2016). 
- Tidak dilakukan pemeriksaan pajak, pemeriksaan bukti permulaan, penyidikan tindak pidana perpajakan, atas kewajiban perpajakan dalam masa pajak, bagian tahun pajak, dan tahun pajak, sampai dengan akhir tahun pajak terakhir.

- penghentian pemeriksaan pajak, pemeriksaan bukti permulaan, dan penyidikan pidana perpajakan, dalam hal wajib pajak sedang menjalani pemeriksaan pajak, pemeriksaan bukti permulaan, dan penyidikan pidana perpajakan atas kewajiban pajak sampai dengan akhir tahun pajak berakhir.

- Adanya fasilitas dalam pengampunan pajak sebagaimana tersebut di atas, merupakan ketidak adilan. Hal ini dikarenakan ada perlakuan khusus terhadap wajib pajak yang tidak patuh membayar pajak, justru diampuni untuk tidak membayar utang pajaknya , sanksi administrasinya, sanksi pidana pajaknya dan sebagainya setelah membayar uang tebusan.

Hal tersebut tidak sesuai dengan sistem hukum bahwa semua warga negara sama di depan hukum. Setiap warga negara (yang memenuhi syarat sebagi wajib pajak) wajib membayar pajak sesuai dengan ketentuan yang berlaku. Hal ini juga seperti yang terdapat dalam asas equality yang dikemukakan oleh Adam Smith yang pada prinsipnya negara tidak boleh diskriminasi dalam pemungutan pajak.

Adanya UU Pengampunan Pajak ini, justru memberikan ampunan kepada wajib pajak yang tidak membayar pajak. Kebijakan ini, merupakan insentif bagi para pengemplang pajak, orang dan perusahaan yang tidak patuh membayar pajak, para manipulator pajak, perusahaan dan orang yang melakukan penipuan pajak, perusahaan asing yang melarikan pajak ke luar negeri melalui transfer pricing. Hal ini dirasakan tidak adil oleh wajib pajak yang selama ini telah patuh membayar pajak sesuai dengan ketentuan undang-undang (dengan tarip yang tentunya lebih tinggi dibandingkan dengan uang tebusan).

2. Dapat Menimbulkan Sikap Ketidak Patuhan Wajib Pajak Untuk Tidak Membayar Pajak Dulu , Karena Berharap Ada Tax Amnesty Di Masa Yang Akan Datang

- Kepatuhan wajib pajak antara lain dipengaruhi oleh kepastian hukum dalam penerapan sanksinya, apabila tidak ada ketidakpastian dalam penerapan sanksi maka hal ini mempengaruhi kepatuhan wajib pajak tersebut, wajib pajak cenderung untuk tidak mentaati ketentuan-ketentuan yang berlaku. Hal ini juga berlaku dalam ketentuan-ketentuan di bidang perpajakan. Sanksi -sanksi di bidang perpajakan harus 
diterapkan sebagaimana mestinya, terhadap wajib pajak yang kurang patuh atau tidak patuh dalam melakukan pembayaran pajak, seharusnya dilakukan tindakan penagihan dan diberikan sanksi-sanksi yang diatur dalam undang-undang, bukan sebaliknya diberikan pengampunan. Adanya tax amnesty, ini tentunya dapat menimbulkan sikap wajib pajak untuk tidak membayar pajak terlebih dahulu karena berdasarkan pengalamannya dengan tax amnesty, pembayaran pajaknya jauh lebih mjurah, sehingga berharap ada kebijakan tax amnessty untuk tahap berikutnya / di masa yang akan datang. Oleh karena itu, pemerintah dalam pelaksanaan tax amnesty beberapa waktu yang lalu, terus mengaskan bahwa tax amnesty yang dilakukan saat ini adalah yang terakhir, tidak ada tax amnesty lagi di masa yang akan datang.

- Tax amnesty merupakan alat untuk menghimpun penerimaan negara dari sektor pajak (tax revenue) secara cepat dalam jangka waktu yang relatif singkat, Namun dalam jangka panjangnya dapat berakibat buruk yatu menurunya keapatuhan sukarela (Voluntay compliance) bilamana program tax amnesty dilaksanakan dengan program yang tidak tepat. ${ }^{11}$

- Efek negatif dari tax amnesty adalah pada kepatuhan sukarela, WP memiliki harapan yang tinggi dari tax amnesty dan akan menjadi kebiasaan. ${ }^{12}$

\section{Bertentangan Dengan Penegakan Hukum Pajak}

Penegakan hukum merupakan serangkaian upaya, proses,dan aktifitas untuk menjadikan hukum berlaku sebagaimana mestinya. ${ }^{13}$ Prinsipnya dalam penegakan hukum, khususnya di bidang hukum pajak, mereka yang kurang atau tidak patuh dalam pelaksanaan kewajiban perpajakan seharusnya dilakukan penegakan hukum dengan memberikan sanksi sebagaimana yang diatur dalam undang-undang pajak.

Adanya tax amnesty yang dilakukan oleh pemerintah ini juga tidak sesuai dengan perinsip penegakan hukum. Kebijakan tax amnesty bertentangan dengan penegakan hukum khususnya penegakan hukum pajak. Sebagaimana diketahui tahun 2016 merupakan tahun penegakan hukum pajak yang dicanangkan Direktorat Jenderal Pajak. Tahun 2016 sebagai tahun penegakan hukum sebagai upaya lanjutan atas program di tahun 2015, yaitu tahun pembinaan pajak yang memberikan kesempatan kepada WP untuk melaporkan dan atau membetulkan kewajiban perpajakannya

\footnotetext{
${ }^{11}$ http://jurnal.unpad.ac.id/sosiohumaniora/article/view/5413, diakses tgl 23 april 2019.

12 Jurnal akutansiI volume. 4 Nomor. 2 Desember 2016,Universitas Sarjanawiyata, Tamansiswa,Jogjakarta

${ }^{13}$ Y . Sri Pudyatmoko, Penegakan dan Perlindungan Hukum, Jakarta : Salemba Empat, 2007, halaman 11.
} 
sebenar-benarnya.Tahun 2016 sebagai tahun penegakan hukum DJP akan menggiatkan kegiatan pemeriksaan maupun penyidikan pajak sebagai langkah untuk mengejar kewajiban pajak yang tidak atau belum dilaporkan WP dan akan melakukan tindakan hukum baik secara hukum administrasi pajak maupun pidana apabila terindikasi adanya tindak pidana pajak.

Berdasarkan pencanangkan tahun 2016 sebagai tahun penegakan hukum oleh DJP tersebut, maka adanya program pengampunan pajak tidak sesuai dengan hal tersebut. Program pengampunan pajak tidak sesuai dengan prinsip-prinsip penegakan hukum. Berdasar asas Certainty yang dikemukakan Adam Smith, maka demi kepastian hukum seharusnya mereka yang melanggar hukum harus dikenakan sanksi, bukan diampuni.

\section{Penutup}

Berdasarkan uraian dalam latar belakang di atas, dapat disimpulkan hal-hal sebagai berikut : 1). Pelaksanaan kebijakan tax amnesty di Indonesia yang dilakukan pada tahun 2016, dapat dikatakan berhasil khususnya dari penerimaan uang tebusan yang berasal dari deklarasi, namun tidak berhasil dari repatriasi. Mengenai jumlah peserta yang ikut program tax amnety, tidak mencapai jumlah peserta yang diharapkan pemerintah. 2). Sisi negatif dari pelaksanaan tax amnesty di indonesia adalah menimbulkan rasa ketidak adilan khususnya bagi wajib pajak yang patuh. Disamping itu, tax amnesty dapat menimbulkan rasa ketidakpatuhan bagi wajib pajak karena wajib pajak berharap ada tax amnesty di masa yang akan datang, sisi negatif lainnya, tax amnesty ini tidak sesuai dengan prinsip penegakan hukum, karena wajib pajak yang kurang atau tidak patuh seharusnya dikenakan sanksi tetapi malah diampuni.

\section{Daftar Pustaka}

Jurnal Akutansi ,Volume 4 Nomor 2, Desember 2016, Universitas Sarjanawiyata, Tamansiswa, Jogjakarta

Kompas com.23-2-2017, Kurniawan,Panca, Bagus Pamungkas, Penagihan Hukum Pajak Di Indonesia, Malang: Bayumedia Publishing, 2016

Peraturan Menkeu Nomor 118/PMK 03/2016 tentang Pelaksanaan UU Nomor 11 tahun 2016 tentang Pengampunan Pajak.

Pudyatmoko,Y . Sri, Penegakan dan Perlindungan Hukum, Jakarta : Salemba Empat, 2007.

Sakti, Nufransa Wira, Asrul Hidayat, Tax Amnesty itu Mudah, Jakarta : Visimedia,2016

Sudjarwadi, Djangkung, "Sosialisasi Akses Informasi Keuangan Bagi Perpajakan", Round Table Discussion, Fakultas Hukum Universitas Diponegoro, Semarang, 14 Juni 2017. 
Undang Undang Nomor 28 Tahun 2007 tentang Perubahan Undang Undang Nomor 6 Tahun 1983 tentang Ketentuan Umum dan Tatacara Perpajakan

Undang-undang Nomor 11 Tahun 2016 tentang Pengampunan Pajak 